\title{
Brincando na Espera
}

\author{
Cavalcante, Alexandra Santos de Souza; Luzo, Maria Candida de Miranda; \\ Almeida, Ligia Cortez de; Reis, Valéria Aquilino \\ Intituto de Ortopedia e Traumatologia - HCFMUSP — alexandra.cavalcante@yahoo.com.br
}

Introdução o brincar ajuda a tornar o ambiente hospitalar menos hostil a doença proporcionando a criança a possibilidade de manter a sua rotina lúdica utilizando um recurso condizente no controle da ansiedade inerente ao processo de tratamento pelas visões estranhas à sua volta e medo do desconhecido. o acolhimento a criança no ambiente hospitalar seja na internação ou na atenção ambulatorial deve considerar os aspectos clínicos e patológicos da doença e suas limitações, mas sobretudo, considerar o aspectos saudável resgatando sua autoestima e potencialidades, normalmente latentes durante o processo de doença e internação. Este projeto é uma extensão da brinquedoteca que atende crianças com diagnósticos diversos mantido por uma recreacionista no ambulatório. Objetivo Criar um local de descobertas e estimulação na sala de espera do ambulatório, onde a criança libera a sua criatividade e imaginação, fazendo com que o tempo de espera seja menos estressante. o Brincando na Espera é muito importante para a criança no aguardo da consulta pois diminui o medo e a angustia que habitam o seu imaginário. Metodologia o Brincando na Espera usa a sala de espera do ambulatório de especialidades em um espaço delimitado montado em dois dias da semana, segunda-feira e quinta-feira, dias de pico de atendimento infantil no ambulatório. a área é delimitada por pedestais de fita retrátil e o espaço é organizado com tapete de EVA, mesas cadeiras infantis, brinquedos livros, jogos, papel, lápis de cor, tinta. o material utilizado é levado pela profissional em um carrinho de apoio especialmente utilizado para esse fim. São realizadas atividades lúdicas e pedagógicas, expressivas e temáticas de acordo como o calendário de datas comemorativas. a participação é voluntária tanto das crianças quanto dos acompanhantes e cuidadores e o tempo de permanência de acordo com o tempo de espera ou a vontade da criança. Resultados: o Brincando na Espera acontece há 7 anos e no ano de 2013, 1450 crianças foram acolhidas no espaço. a mensuração dos resultados foi feita pelo depoimento dos acompanhantes e profissionais os quais constataram que as crianças deixaram de temer a vinda ao hospital e de chorar antes e durante os procedimentos clínicos. Conclusão Neste ambiente criado para a brincadeira, o ato do brincar passa a ser visto como um fator primordial no tratamento, pois é capaz de oferecer não só alegria mas também facilitar a interação do profissional da saúde com a criança no momento do atendimento, além de acolher a ansiedade e controlar o estresse. o Brincando na Espera incentiva o brincar, a leitura, a vivencia com outras crianças na situação semelhante e possibilita levar para casa a sua atividade, assim como o que aprendeu durante a espera da consulta.

Cavalcante, Alexandra Santos de Souza; Luzo, Maria Candida de Miranda; Almeida, Ligia Cortez de; Reis, Valéria Aquilino. Brincando na Espera. In: Anais do Congresso Internacional de Humanidades \&

Humanização em Saúde [= Blucher Medical Proceedings, num.2, vol.1]. São Paulo: Editora Blucher, 2014. ISSN 2357-7282

DOI 10.5151/medpro-cihhs-10639 